\title{
Coronary artery fistula: a huge conus branch aneurysm
}

\author{
Fatemeh Moodii ${ }^{1}$, Sarah Tayebi ${ }^{1}$, Jalal Soltani ${ }^{1}$, Fahime Sadat Saleh ${ }^{2}$, Hami Ashraf ${ }^{1}$, Afsoon Fazli Nezhad ${ }^{1}$ \\ ${ }^{1}$ Education and Research Department, Razavi Hospital, Mashhad, Iran \\ ${ }^{2}$ Farabi Hospital, Mashhad, Iran
}

Kardiochirurgia i Torakochirurgia Polska 2014; 11 (4): 441-443

\begin{abstract}
Coronary artery fistulas are rare coronary-cardiac anomalies, which occasionally become symptomatic. We herein report a case of a 54-year-old woman with a huge conus branch aneurysm resulting from an abnormal fistula between the conus branch and the upper portion of the right atrium, which was successfully removed by surgery.
\end{abstract}

Key words: conus branch aneurysm, coronary artery fistula.

\section{Introduction}

A coronary artery fistula is an abnormal connection between a coronary artery and major vessels or cardiac chambers. It is a rare condition with incidence ranging from $0.1 \%$ to $0.2 \%$ in the general population [1]. However, it has been reported that this incidence varies between $0.6 \%$ and $1.5 \%$ in patients undergoing invasive cardiovascular imaging $[2,3]$. The most common site of origin for coronary-cardiac fistulas is the right coronary artery (RCA), and approximately $40 \%$ of these arteries drain into the right ventricle or right atrium [1].

The condition is usually asymptomatic, and most cases are revealed by chance during other evaluations. Sometimes, usually after childhood, coronary artery fistulas, especially fistulas draining into the right-side chambers, can become symptomatic by shunting away the myocardial blood flow or backward overload. Fatigue, angina pectoris, palpitations, dyspnea (particularly exertional dyspnea), heart murmur, and even heart failure have been reported in terms of accompanying symptoms $[4,5]$.

Considering the low incidence of this condition and limited previous reports, the management of coronary-cardiac fistulas poses a challenge. Almost all reports state that the closure of a fistula is indicated only when the patient is symptomatic, and prophylactic closure, especially in children, is controversial [6].

At present, the closure of coronary-cardiac fistulas is possible through interventional catheterization techniques, which appear to be the treatment of choice in children $[7,8]$.

\section{Streszczenie}

Przetoki tętnic wieńcowych stanowią rzadką anomalię sercowo-wieńcową, która czasami może dawać objawy. W pracy przedstawiono przypadek 54-letniej pacjentki z ogromnym tętniakiem gałęzi stożka sercowego spowodowanym nieprawidłową przetoką pomiędzy gałęzią stożka a górną częścią prawego przedsionka. Zmiana ta została skutecznie usunięta podczas operacji.

Słowa kluczowe: tętniak gałęzi stożka sercowego, przetoka tętnicy wieńcowej.

However, it seems that surgical closure is safer and more effective, constituting the treatment of choice in most cases $[9,10]$.

\section{Case report}

A 54-year-old female patient was referred to our center with a history of 4 months of progressive dyspnea. She did not mention any particular history of cardiovascular disease, and had not undergone any previous intervention.

Transthoracic echocardiography (apical 4-chamber view) revealed a huge $(10 \times 12 \mathrm{~cm})$ cystic cardiac mass located at the interatrial septum with a compressive effect on both atria (Fig. 1).

The dimensions of right atrial (RA) and left atrial (LA) were slightly reduced. In the parasternal view, a dilatation was observed at the end of the RCA with continuous abnormal flow from the RCA to the cyst. The flow entered from the RCA, and no obvious exit was detected, but we could see a significant smoky circular shadow, particularly at the central area of the cyst, as well as swirling color flow in the circumference (Fig. 2).

The patient's Qp/Qs ratio in the continuity equation not catheterization - was 1.3/1.

We found no evidence of a significant left-to-right shunt, probably due to the very small size exit site of the fistula.

Coronary angiography showed normal coronary arteries. Selective right coronary artery injection revealed an 


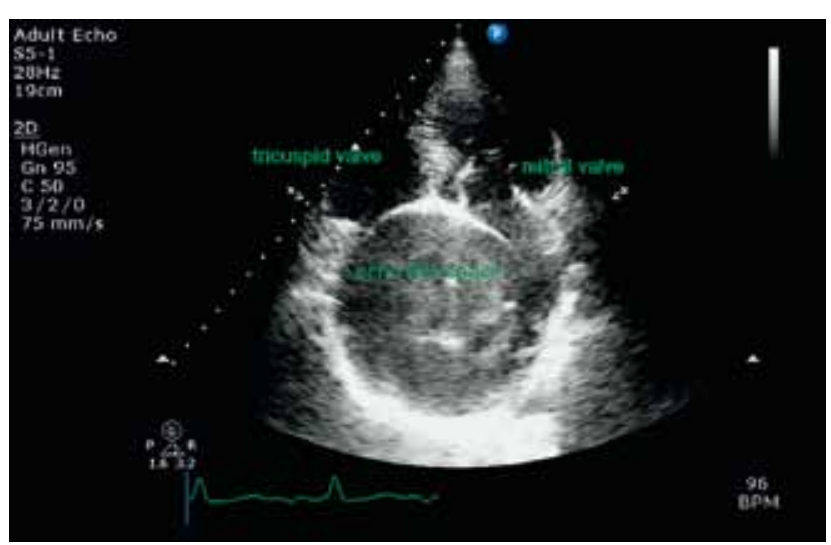

Fig. 1. Transthoracic echocardiography (apical 4-chamber view): huge cystic cardiac mass located at the interatrial septum with a compressive effect on both atria

unusual finding of a coronary artery fistula originating from the conus branch and draining into a huge cystic mass. However, we were not sure whether it entered the coronary sinus or the right atrium. The patient did not consent to undergo cardiac MRI or CT.

The patient underwent surgery with sternotomy and cardiopulmonary arrest. The aneurysm size was $10 \times 12 \mathrm{~cm}$, and it was located between the AAO on the left side and the RAA on the right side, bound superiorly by the innominate vein, inferiorly by the RA, and posteriorly by the LA and RPA.

After dissecting the mentioned aneurysm, we discovered that the fistula originated from the conus branch of the RCA, entering the upper portion of the RA through a very small opening.

The aneurysm was removed, and the entrance of the fistula into the upper portion of the RA was sutured. We explored the heart for another possible anatomical abnormality, but no abnormality was found.

The postoperative course was uneventful, and the patient was discharged 6 days later with no remaining dyspnea and in a stable condition.

\section{Discussion and conclusion}

Coronary-cardiac fistulas are rare; most of them originate from the RCA and drain into the right ventricle (40\%), right atrium, pulmonary artery, left atrium, coronary sinus, brachial veins, or even the superior vena cava [1].

The condition is usually asymptomatic. In most symptomatic patients, the symptoms usually begin after the third decade; therefore, in the absence of coronary artery disease, exertional angina is the most relevant finding [5].

Although rare, congestive heart failure, endocarditis, aneurysmal dilatation and rupture are reported as well [11].

The treatment of asymptomatic coronary-cardiac fistulas is controversial, and most authors agree that, in order to avoid late complications, treatment should be restricted to symptomatic cases. On the other hand, some believe that, in the presence of significant shunt or aneurysmal dilatation, closure should be performed, even though the patient is asymptomatic [1].
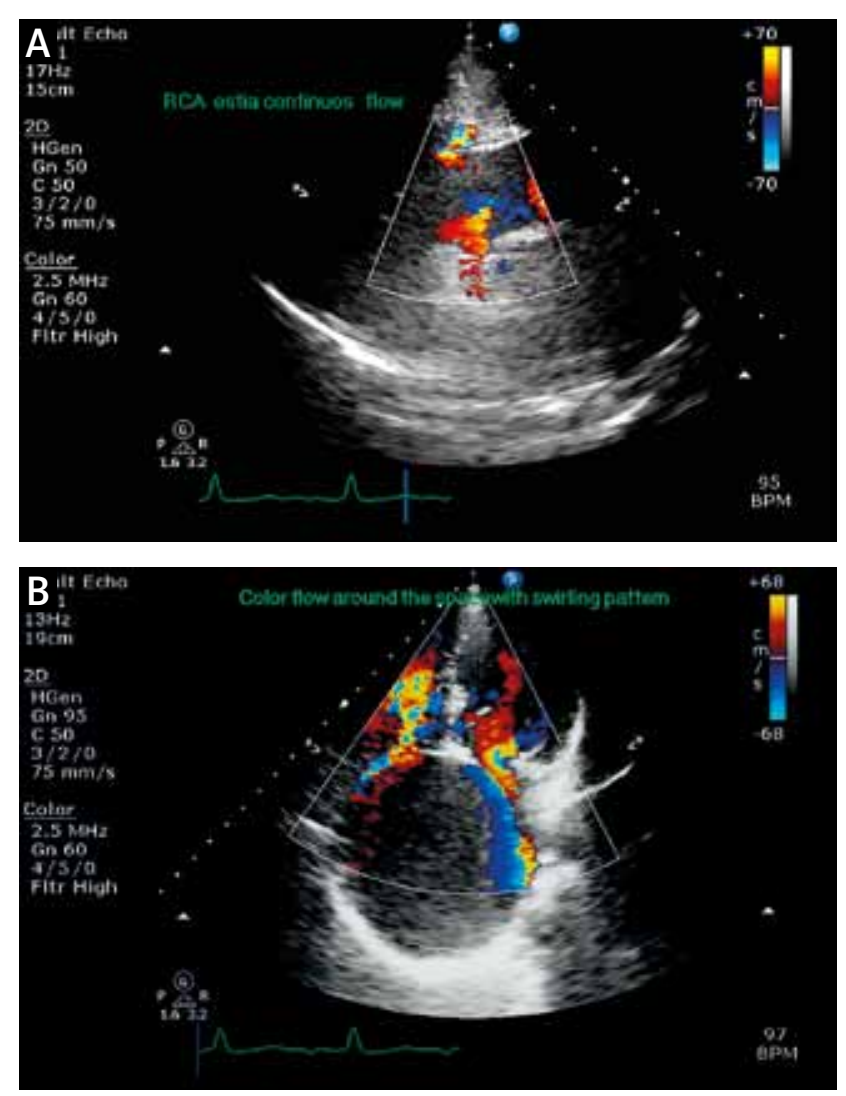

Fig. 2. A) Transthoracic echocardiography (parasternal view): dilatation at the end of the RCA with continuing abnormal flow from the RCA to the cyst. B) Apical 4-chamber view: color view revealed swirling color flow in the circumference of the cyst

Despite the development of various high-tech methods of interventional catheterization closure, most authors still agree that surgical closure is the gold-standard treatment in adults. Transcatheter closure is the preferred method of treatment in symptomatic pediatric cases [12].

Using on-pump or off-pump techniques and sternotomy or the minimally invasive approach is controversial.

The highlights of our case include the uncommon presenting symptom (exertional dyspnea), the huge size of the aneurysm $(10 \times 12 \mathrm{~cm})$, as well as its rare origin (the conus branch), entrance into the upper portion of the right atrium, and very small exit size with no significant effect on the chambers' size. In this case, because of the unclear site of entrance, we decided to employ on-pump surgery using a sternotomy approach.

\section{Disclosure}

Authors report no conflict of interest.

\section{References}

1. Fernandes ED, Kadivar H, Hallman GL, Reul GJ, Ott DA, Colley DA. Congenital malformations of the coronary arteries: the Texas Heart Institute experience. Ann Thorac Surg 1992; 54: 732-740.

2. Kardos A, Babai L, Rudas L, Gaál T, Horváth T, Tálosi L, Tóth K, Sárváry L, Szász K. Epidemiology of congenital coronary artery anomalies; a coronary arteriography study on a Central European population. Cathet Cardiovasc Diagn 1997; 42: 270-275. 
3. Malouf JF, Edward WD, Tajik AJ, Seward JB. Functional anatomy of the hearth. In: Hurst's the Heart. Fuster VAR (ed.). McGraw Hill, New York 2004.

4. Vijavvergiya R, Bhadauria PS, Jeevan H, Mittal BR, Grover A. Myocardial ischemia secondary to dual coronary artery fistulas draining into main pulmonary artery. Int J Cardiol 2010; 140: e30-33.

5. Vijayvergiya R, Bhadauria PS, Jeevan H, Mittal BR, Grover A. Myocardial ischemia secondary to dual coronary artery fistulas draining into main pulmonary artery. Int J Cardiol 2010; 140: 30-33.

6. Koneru J, Samuel A, Joshi M, Hamden A, Shamoon FE, Bikkina M. Coronary Anomaly and Coronary Artery Fistula as Cause of Angina Pectoralis with Litreture Review. Case Rep Vasc Med 2011; 2011: 486187.

7. Hartnell GG. Embolization in the treatment of acquired and congenital abnormalities of the heart and thorax. Radiographic 1993; 13: 1349-1363.
8. Dorros G, Thota V, Ramireddy K, Joseph G. Catheter-based techniques for closure of coronary fistula. Catheter Cardiovasc Interv 1999; 46: 143-150.

9. Kamiya H, Yasuda T, Nagamine H, Sakakibara N, Nishida S, Kawasuji M, Watanabe G. Surgical treatment of congenital coronary artery fistulas: 27 years' experience and a review of the literature. J Card Surg 2002; 17: 173-177.

10. Cheung DL, Au WK, Cheung HH, Chiu CS, Lee WT. Coronary artery fistulas: long-term results of surgical correction. Ann Thorac Surg 2001; 71: 190-195.

11. Marullo AGM, Sabik JF. Right coronary artery and interatrial septal aneu rysms with fistulous connection to the right atrium. Ann Thorac Surg 2002; 73: 969-970.

12. Kung GC, Moore P, McElhinney DB, Teitel DF. Retrograde transcatheter coil embolization of congenital coronary artery fistulas in infants and young children. Pediatr Cardiol 2003; 24: 448-453. 